\title{
OPTIMAL ELECTROPORATION CONDITION FOR SPERM MEDIATED GENE TRANSFER IN STRIPPED CATFISH (Pangasionodon hypophthalmus)
}

\author{
Raden Roro Sri Pudji Sinarni Dewi ")\#, Alimuddin ${ }^{* *}$, Agus Oman Sudrajat", Komar \\ Sumantadinata**), and Sularto") \\ ") Research Institute for Freshwater Fish Breeding and Aquaculture \\ ${ }^{*}$ Department of Aquaculture, Faculty of Fisheries and Marine Science, Bogor Agricultural University
}

(Received 23 February 2010; Accepted 17 May 2010)

\begin{abstract}
The success of transgenic fish production has been achieved through eggs fertilization using electroporated sperms carrying exogenous DNA. This study was conducted in order to obtain the optimal electroporation condition for stripped catfish sperm. A plasmid containing green fluorescent protein (GFP) gene driven by carp $\beta$ actin promoter was transferred into sperm using electrophoresis method towards transgenic stripped catfish (Pangasionodon hypophthalmus) production. Electroporation was carried out using square wave shock with pulse length of $30 \mathrm{~ms}$ and pulse interval of $0.1 \mathrm{sec}$. Treatments are combination between voltage $(50 \mathrm{~V}, 75 \mathrm{~V}$, and $100 \mathrm{~V}$ ) and pulse number ( 1 and 3). Exogenous DNA concentration used was 10 $\mu \mathrm{g} / \mathrm{mL}$ of Tris-EDTA. Results showed that increasing the voltage from 50 to 100 decreased sperm motility, while pulse number did not affect sperm motility. Voltage of 50 gave the best motility of sperm, although sperm viability relatively similar between treatments and control except at $100 \mathrm{~V}$ with 3 pulses number. Further, electroporation-treated sperms were able to fertilize eggs. Higher hatching rate of eggs was obtained in electroporation treatment at $50 \mathrm{~V}$ with pulse number of 1 and 3 . The persistence of transferred GFP was detected in electroporated and incubated sperms (control). However, GFP was only detected in larvae from eggs that were fertilized by electroporated sperm. Thus, electroporation could be applied to produce transgenic stripped catfish.
\end{abstract}

KEYWORDS: electroporation, sperm, Pangasionodon hypophthalmus

\section{INTRODUCTION}

Several techniques are currently available for transgenic fish production, including: microinjection of DNA into pronuclei/nuclei of fertilized eggs (Ozato et al., 1986), egg and semen electroporation (Inoue et al., 1990; Lu et al., 2002), gonad lipofection (Lu et al., 2002), retroviral infection (Lin et al., 1994), and particle gun bombardment (Yazawa et al., 2005). Among them, microinjection has been more extensively used and has achieved a higher degree of success for producing transgenic fish. However, besides being laborious, its success is limited by characteristics of eggs from some species (small size, hard chorion, fragility, opacity, etc.; Lanes et al., 2009). Furthermore, the production of transgenic animals through embryo manipulation is quite expensive and laborious with a success rate that is less than 1\%-4\% (Anzar \& Buhr, 2006).

\# Corresponding author. Research Institute for Freshwater Fish Breeding and Aquaculture, Jl. Raya Sukamandi No.2, Subang 41256, West Java, Indonesia. Tel.: + 62260520500

E-mail address: wiewie_thea@yahoo.com 
Spermatozoa can be a carrier of exogenous DNA due to their natural ability to transfer exogenous DNA into an oocyte and produce transgenic offspring (Anzar \& Buhr, 2006). Brackett et al. (1971) first demonstrated that rabbit sperm are able to pick up exogenous DNA in solution, and this DNA is subsequently localized in the sperm head. Almost two decades later, Arezzo (1989) and Lavitrano et al. (1989) independently showed that sperm cells of sea urchin and mouse could be used as vectors for gene transfer. Sperm-mediated gene transfer (SMGT) is an ideal method for mass gene transfer in organism with external fertilization, such as salmon (Sin et al., 2000). SMGT could be useful to achieve transgenesis in species with high fecundity, small eggs, and easy access to spermatozoa (Lanes et al., 2009).

SMGT was efficient technique in producing transgenic pigs containing human decay accelerating factor (hDAF), with a $64 \%$ transcription rate in the tissues tested. This would be a much simpler technique than microinjection of zygotes and provides the opportunity to carry out transgenesis on mass scale. The binding of exogenous DNA to mouse, chicken, ram and buck, bull, and human spermatozoa has already been reported. Although transgenic animals have been produced in various species, the efficiency of sperm-mediated DNA transfer is still questionable, mainly due to the low uptake of exogenous DNA by spermatozoa, thereby reducing the chances of fertilizing the oocyte with transfected spermatozoa (reviewed by Anzar \& Buhr, 2006).

Based on research, good SMGT results for fish were obtained only when semen was electroporated, as demonstrated for tilapia Oreochromis niloticus, zebrafish Danio rerio, salmon Oncorhynchus tshawytscha, grass carp Ctenopharyngodon idellus, and silver sea bream Sparus sarba (reviewed by Lanes et al., 2009). Compared to the tedious work of microinjection, electroporation is considered to be an easier alternative (Inoue et al., 1990) because electroporation of fertilized eggs can produce 10 to 100 times greater numbers than that microinjection (Powers et al., 1992). However, gene transfer efficiency is still not high enough to handle the tremendously large number of eggs spawned within a very short time by aquacultural species.

There are some advantages in applying the SMGT technique in fish. First, this technology is considered a "mass" gene transfer. Second, this overcomes some disadvantages of conventional gene transfer system resulting from the characteristics of eggs, such as opaqueness, stickiness, bouyancy, invisible pronuclei, and tough chorion. Third, foreign DNA should be transferred into the nucleus. If fertilized eggs are electroporated with foreign DNA, the DNA fragments have a greater chance to be transferred into some places other than into the blastodisc because its volume is extremely small in the fertilized eggs. Fourth, fish sperms are easy to handle because simply adding water is enough to activate them. Fifth, sperm of aquatic animals can be kept by cryopreservation so that treated sperm are always ready for usage. Therefore, fish sperms have been reported as a vector for introducing foreign DNA to produce transgenic fish (Tsai, 2000).

Successful transfer of genes into aquatic organism has been demonstrated by electroporation of sperm using exogenous DNA before fertilization. The efficiency of DNA transfer into ayu Plecoglossus altivelis eggs by the SMGT method was 55\% (Cheng et al., 2002), better than that of $50 \%$ in loach (Tsai et al., 1995), but lower than that of $80 \%$ in zebrafish (Powers et al., 1992). In this study, a plasmid containing green fluorescent protein (GFP) gene was transferred which was driven by common carp $\beta$-actin promoter (pccBA), using a sperm-mediated electroporation method on stripped catfish Pangasionodon hypophthalmus. To obtain an optimal gene transfer efficiency, this research was conducted by the combination of voltage and pulse number on the stripped catfish sperm.

\section{MATERIALS AND METHODS}

\section{Egg and Sperm Collection}

Stripped catfish egg and sperm were collected from the Research Institute for Freshwater Fish Breeding and Aquaculture, Sukamandi. The mature male and female broodstock (body weight 2-4 kg) were checked and separated on the day before fertilization. To induce egg maturation and ovulation, female broodstock were injected twice: The first injection was by HCG at $500 \mathrm{IU} / \mathrm{kg}$ body weight, and the second was performed 24 hours after the first injection by ovaprim at 0.6 $\mathrm{mL} / \mathrm{kg}$ body weight. Eggs were collected 9-12 hours after the second injection. To induce 
spermiation, male broodstocks were injected once by ovaprim at $0.2-0.3 \mathrm{~mL} / \mathrm{kg}$ body weight. After 9-12 hours, sperm was collected by squeezing fish abdomen.

\section{Plasmid Construction}

The recombinant plasmid used in this study was constructed by Hidayani (2009). Kpnl-Apal carp $\beta$-actin promoter (pccBA) fragment is ligated at Kpnl-Apal digested pEGFP-NI (4.7 kb) to construct pccBA-GFP plasmid (Figure 1). Digestion process was performed in a final volume of 50 $\mu \mathrm{L}$ containing $5 \mu \mathrm{L}$ of pEGFP-NI, $2.5 \mu \mathrm{L}$ of $10 x \mathrm{~K}$ buffer, $1 \mu \mathrm{L}$ of Kpnl enzyme, $1 \mu \mathrm{L}$ of Apal enzyme and $35.5 \mu \mathrm{L}$ of sterile distillated water. Digestion reaction was incubated for 1 hour at $37^{\circ} \mathrm{C}$. Ligation process was performed by mixing $1 \mu \mathrm{L}$ of pccBA, $6.5 \mu \mathrm{L}$ of $2 x$ ligation buffer, 1 $\mu \mathrm{L}$ of T4 DNA ligase and $4.5 \mu \mathrm{L}$ of digested pEGFP-NI. The ligation reaction was incubated for 2 hours at room temperature.

\section{Sperm Electroporation}

Sperm electroporation was carried out using Gene Pulser II machine (Biorad, USA). Sperm was diluted with physiological solution $(1: 7)$ before it was mixed with exogenous DNA (plasmid constructs). To obtain the optimal electroporation condition, the preliminary research was conducted to obtain the voltage range that supports high motility and viability of spermatozoa. Voltages attempted were from $100 \mathrm{~V}$ to $500 \mathrm{~V}$. Based on the result of the preliminary study, the electroporated sperm that was shock by voltage of $100 \mathrm{~V}$ showed the best motility and viability of sperm. Further testing was conducted with combination of voltage and pulse number to obtain the optimal sperm motility, sperm viability, fertilization rate, hatching rate, and successful of exogenous DNA transfer in sperm and larvae. Voltages tested in this study were $50 \mathrm{~V}, 75 \mathrm{~V}$, and $100 \mathrm{~V}$ combined with pulse number 1 and 3. Electroporation was carried out by square wave type shock with pulse length of 30 milliseconds and pulse interval of 0.1 seconds. Exogenous DNA concentration applied was $10 \mu \mathrm{g} / \mathrm{mL} \mathrm{TE}$.

\section{Motility and Viability of Spermatozoa}

Sperm motility was estimated as the percentage number of motile sperm. One drop of sperm was placed on object glass and then covered with cover glass. At the edge of the cover glass, a drop of the water was added, and the spermatozoa motility was monitored under microscope with magnification of $10 x$ 40. Motility index based on the number of spermatozoa motile was shown in Table 1.

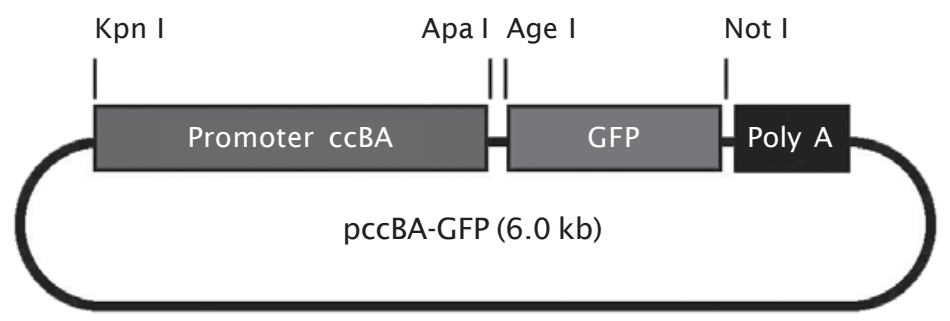

Figure 1. Gene construction map of pccBA-GFP (6.0 kb)

Table 1. Index motility of spermatozoa

\begin{tabular}{lc}
\hline \multicolumn{1}{c}{ Crit eria } & Score \\
\hline$>70 \%$ of spermatozoa moving forward quic kly & 5.0 \\
$55 \%-70 \%$ of spermatozoa moving forward and some showed quick movement & 4.0 \\
$40 \%-55 \%$ of spermatozoa moving forward and some showed quick movement & 3.0 \\
$25 \%-40 \%$ of spermatozoa moving forward & 2.0 \\
$10 \%-25 \%$ of spermatozoa moving forward & 1.0 \\
$1 \%-10 \%$ of spermatozoa moving forward, most of spermatozoa was immotile & 0.5 \\
All spermatozoa was immotile & 0.0 \\
\hline
\end{tabular}


The viability of electroporated sperm was observed through Eosin staining. For staining preparation, sperm was dropped on the glass object and mixed with $2 \%$ Eosin. It was dried at room temperature and then rinsed with aquades. The staining preparations were observed under microscope with magnification of $10 \times 40$ with 3 fields of view. Live spermatozoa is characterized by red and round spermatozoa heads, while dead spermatozoa head are black and irregularly shaped (Figure 2).

\section{DNA Extraction}

To separate sperm from exogenous DNA which has not attached to the sperm membrane, the sperms were centrifugated at 3,000 rpm for 1 minute and washed three times in physiological solution. Genomic DNA was extracted from sperm and larvae by using commercial kit (Puregene, Minneapolis, USA).

\section{Polymerase Chain Reaction}

PCR was performed to detect exogenous DNA (GFP) in sperm and larvae. One microliter of DNA extract was used as a template for PCR, and then mixed with $1 \mu \mathrm{L}$ GFPr primer (5'-ACG AAC TCC AGC AGG ACC AT-3'), $1 \mu$ L GFPf primer (5'-GGT CGA GCT GGA CGG CGA CG-3'), $1 \mu \mathrm{L}$ dNTPs, $1 \mu \mathrm{L}$ Ex Taq buffer, $0.05 \mu \mathrm{L}$ Ex Taq polymerase (TAKARA Bio) and $5 \mu \mathrm{L}$ SDW. PCR was programmed as follows: $94^{\circ} \mathrm{C}$ for 3 minutes; $\left(94^{\circ} \mathrm{C}\right.$ for 30 seconds, $62^{\circ} \mathrm{C}$ for 30 seconds, $72^{\circ} \mathrm{C}$ for 1 minute) of 35 cycles, $72^{\circ} \mathrm{C}$ for 3 minutes and $4^{\circ} \mathrm{C}$ (unlimited). PCR amplification product was electrophoreted using $0.7 \%$ agarose gel.

\section{RESULTS AND DISCUSSION}

\section{Motility and Viability of Electropo- rated and Non Electroporated Sperm}

A preliminary test was conducted to obtain the optimal voltage of electroporation on stripped catfish sperm. Based on the preliminary research, motility of spermatozoa was decreased by the increase of voltage. Sperm that was electroporated with $100 \mathrm{~V}$ showed the best motility (Table 2). Further, spermatozoa viability was also decreased by the increase of voltage. Spermatozoa viability with electroporation at $100 \mathrm{~V}$ and $200 \mathrm{~V}$ showed similar pattern and significantly higher compared to $300 \mathrm{~V}, 400 \mathrm{~V}$, and $500 \mathrm{~V}$ (Figure 3).

Further study was conducted to obtain the optimal electroporation conditions. Sperms were electroporated with combination of voltage $(50 \mathrm{~V}, 75 \mathrm{~V}$, and $100 \mathrm{~V})$ and electric pulse number ( 1 and 3 ). As shown in Table 3 and Figure 4, increasing the voltage from 50 to 100 decreased sperm motility, but electric pulse number did not affect sperm motility. Voltage of 50 gave the best motility. However, sperm viability was relatively similar between treatments and control, except at $100 \mathrm{~V}$ with three pulse electric number. Thus, treatment at $50 \mathrm{~V}$ with electric pulse number of 1 and 3 was the optimum condition for electroporation of sperm stripped catfish.

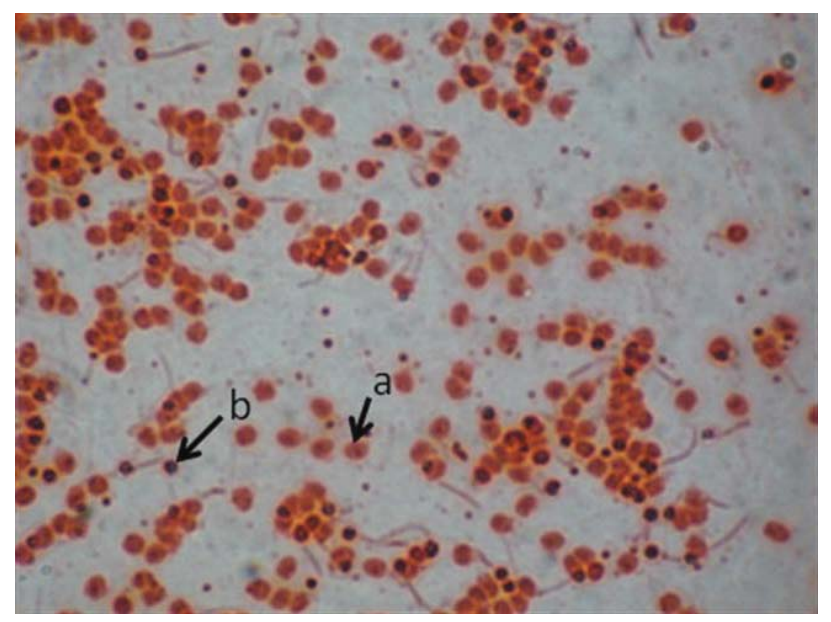

Figure 2. Electroporated sperm ( $a=$ live spermatozoa, $b=$ dead spermatozoa) 
Table 2. Spermatozoa motility that was electroporated with different levels of voltage

\begin{tabular}{cc}
\hline Volt age $(V)$ & Motility index \\
\hline Control & 4.0 \\
100 & 3.0 \\
200 & 2.0 \\
300 & 1.0 \\
400 & 0.5 \\
500 & 0.0 \\
\hline
\end{tabular}

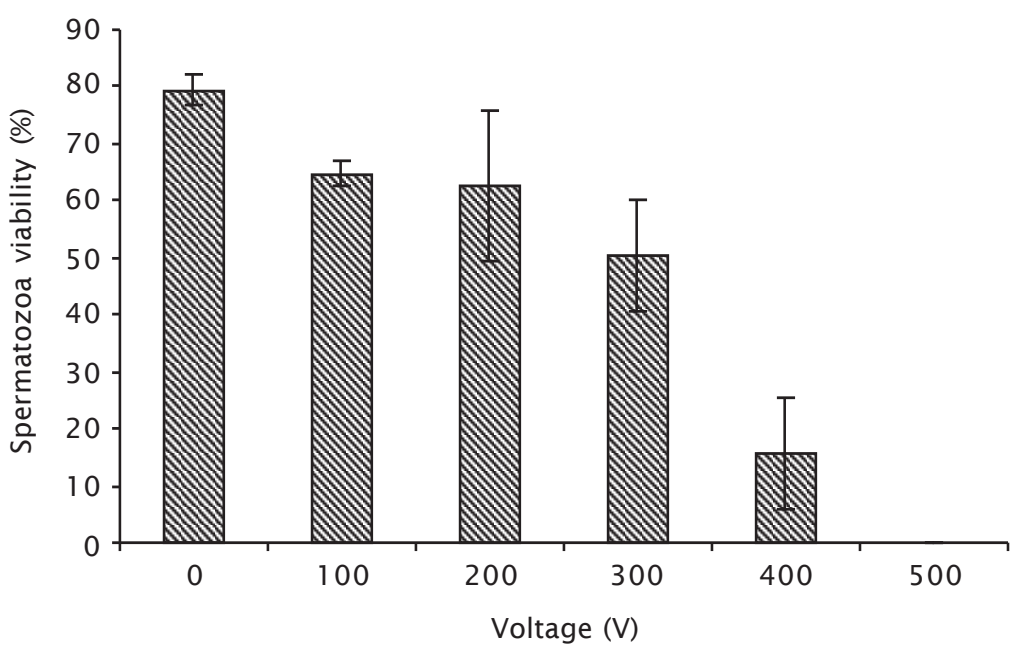

Figure 3. Spermatozoa viability (\%) with different levels of electroporation voltage

Tabel 3. Motility of the spermatozoa subjected to different combination of voltage and pulse number

\begin{tabular}{lllllc}
\hline \multirow{2}{*}{ Treat ment s } & \multicolumn{5}{c}{ Voltage $(\mathrm{V})$} \\
\cline { 2 - 6 } & & $\mathbf{0}$ & $\mathbf{5 0}$ & $\mathbf{7 5}$ & $\mathbf{1 0 0}$ \\
\hline Pulse number & 1 & 5 & 3 & 3 & 2 \\
& 3 & 3 & 3 & 2 & 2 \\
\hline
\end{tabular}

The application of an electric pulse to a cell suspension induces polarization of the membrane components of living cells and develops a voltage potential across the membrane. When the potential difference between the inside and the outside of the cell membrane passes a critical level, the membrane components are reorganized into pores in localized areas, and therefore the cells become permeable to the entry of macromolecules (Knight, 1981; Knight \& Scrutton, 1986). The process of modifying the permeability of the cell membrane by an electric field is called electroporation. The change in permeability is transient, provided that the electric pulse does not exceed a critical limit for that particular cell (Tsong, 1983; Serpeusu et al., 1985). For stripped catfish, sperm viability that was 


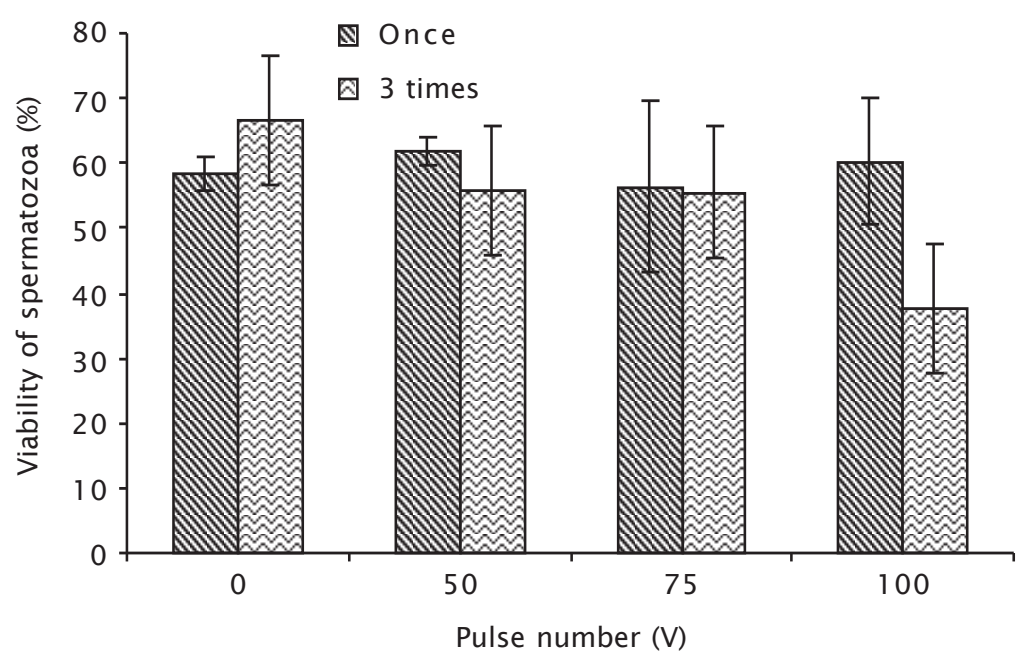

Figure 4. Viability (\%) of the spermatozoa subjected to different combination of voltage and pulse number

electroporated at $50 \mathrm{~V}$ was $58.4 \%-66.5 \%$, but electroporation at $500 \mathrm{~V}$ had killed the sperm. Cheng et al. (2002) demonstrated that the mortality of ayu sperm decreased to $50 \%$ after 120 $\mathrm{s}$ when $9 \mathrm{kV}$ was used. In salmon, the activity of salmon sperm decreased from $82 \%$ to $2 \%$ as sperm were electroporated at voltage increasing from 625 to $1,000 \mathrm{~V} / \mathrm{cm}$ (Symonds et al., 1994). The sperm motility, a measure of sperm viability, after electroporation is dependent on the field strength, pulse length, pulse number, and ionic strength of the buffer (Symonds et al., 1994). The pore size can be changed by varying the pulse length (in milliseconds), field strength (in Volts/centimeter), and ionic strength of the media (Tsong, 1983).

Sperm electroporated at $50 \mathrm{~V}, 75 \mathrm{~V}$, and $100 \mathrm{~V}$ still have capability to fertilize eggs. Figure 5, the ability of sperm electroporated at $50 \mathrm{~V}$ and $75 \mathrm{~V}$ with electric pulse number 1 to fertilize eggs was similar and higher than $100 \mathrm{~V}$, but when electroporated at pulse

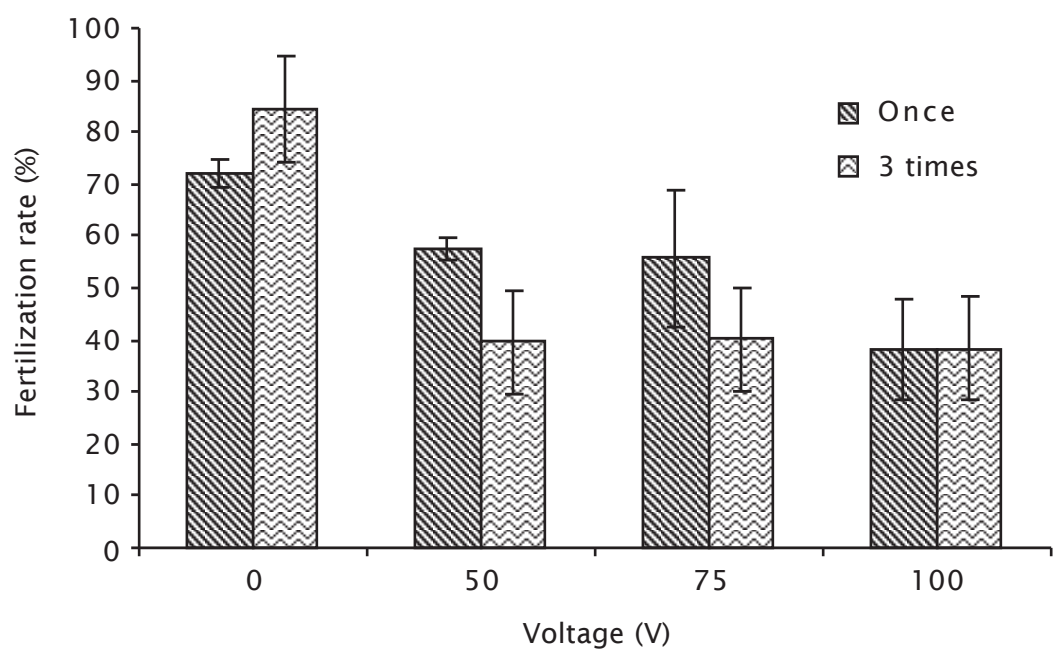

Figure 5. Fertilization rate (\%) of eggs that were fertilized by the spermatozoa subjected to different combinations of voltage and pulse number 
number 3 , the results were similar among treatments. In addition, hatching rate of eggs fertilized by electroporated sperm tended to decrease by increasing voltage. Eggs fertilized by sperm that was electroporated at $50 \mathrm{~V}$ with pulse number 1 and 3 showed the best hatching rate (Figure 6).

Sperm condition (motility and viability) will determine the success of fertilization. A good sperm can fertilize an egg properly. A good quality of sperm that is eligible for fertilization, contain the life and active moving forward (progressive) sperm. Spermatozoa with $75 \%$ of motility, is good enough for fertilization. Although, for aquaculture practice, sperm with motility $50 \%-60 \%$, still have a good quality for fertilization (Hafez, 1987). Hatching rate of eggs that was fertilized by electroporated sperm at $50 \mathrm{~V}$ was indifferent with the control. Hatching rate was decreased when eggs were fertilized by electroporated sperm from (92.5\%-100\%) to (58.6\%-66.9\%) (Figure 6).

\section{Transgene Detection on Spermatozoa and Larvae}

The presence of GFP gene in electroporated stripped catfish spermatozoa was shown in Figure 7. GFP gene was detected in all treatments, both in the sperm that was incubated with exogenous DNA (control) or in the electroporated sperm. However, in larvae, the GFP gene was only detected in the larvae from egg that was fertilized by electroporated sperm. The larvae developed from eggs fertilized by sperms which were simply incubated in medium containing GFP gene (K), did not show any GFP amplification product (Figure 8).

Lanes et al. (2009) reported, if semen was incubated with exogenous DNA but not electroporated, the efficiency of SMGT for transgenic fish production was low or nonexistent. Zhong et al. (2002) demonstrated, grass carp sperms were mixed with pCAhLFc and incubated for 10-30 minutes, then added to the eggs for artificial fertilization. The efficiency of such gene transfer was between $2.2 \%$ and $4.3 \%$. The rate of success of gene transfer among fry developing from eggs fertilized with electroporated-sperm was between $19.6 \%$ and $46.8 \%$.

Mature sperm cells of zebrafish (Danio rerio) incubated with foreign DNA have the capacity to take up foreign DNA. Such uptake can be enhanced by electroporation. Frequency of transgenic individuals as monitored by polymerase chain reaction, increased marginally, more than doubled and nearly doubled in 500 $\mathrm{V} / \mathrm{cm} ; 1,000 \mathrm{~V} / \mathrm{cm}$; and $1,500 \mathrm{~V} / \mathrm{cm}$ electroporated groups, respectively, when compared to the non-electroporated group. The increased field strength, however, had a deleterious effect on the motility of the sperm, causing clumping of sperm at high voltages (Patil \& Khoo, 1996).

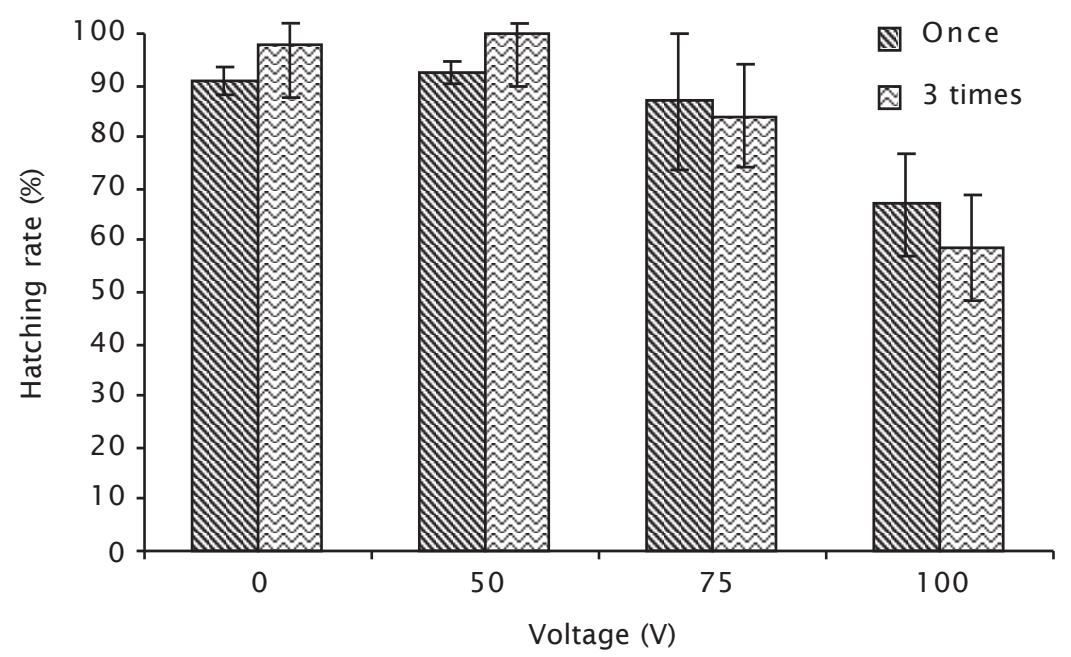

Figure 6 . Hatching rate (\%) of eggs fertilized by the spermatozoa subjected to different combinations of voltage and pulse number 


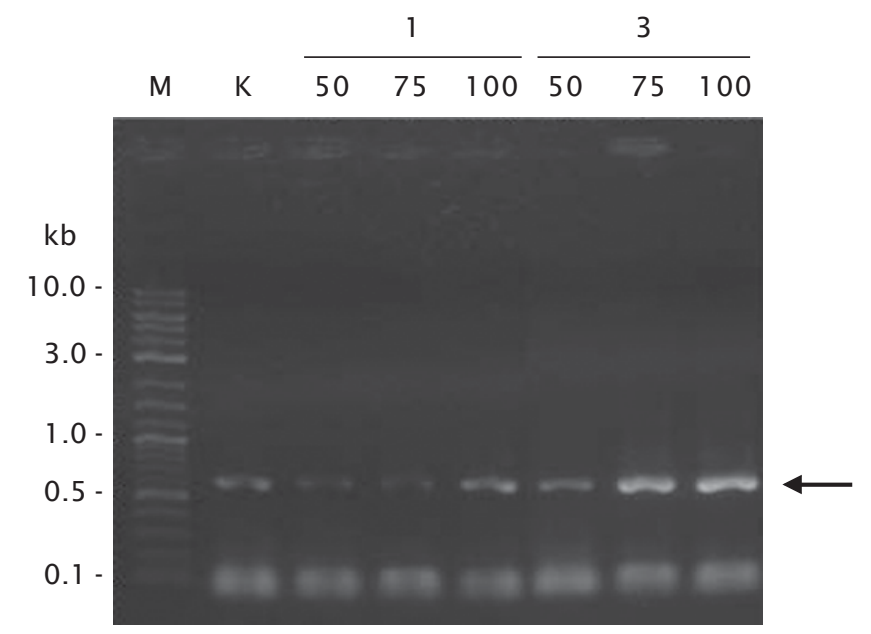

Figure 7. The presence of GFP gene (arrow sign) in electroporated and non electroporated (K) stripped catfish spermatozoa. M = DNA marker (2-log ladder); numbers 1 and 3 show the pulse number; 50, 75, and 100 were voltage. Numbers on the left image is the size of fragment DNA markers

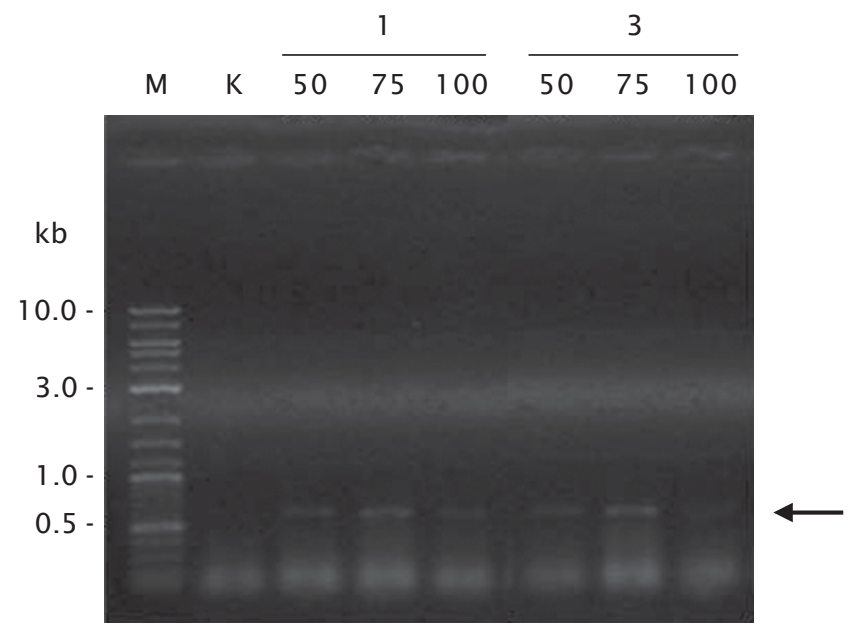

Figure 8. The presence of GFP gene (arrow sign) in stripped catfish larvae. $\mathrm{K}=$ control; $\mathrm{M}=$ marker DNA (2-log ladder); numbers 1 and 3 show the pulse number; 50, 75, and 100 were voltage. Numbers on the left image is the size of fragment DNA markers

The success of GFP gene transfer through electroporation method in Stripped catfish sperm opens opportunities for the production of transgenic Stripped catfish. Increased production of Stripped catfish fish needed to deal with issues of increasing of human population, worsening environmental conditions, and increasing public awareness about highly nutritious food. Introduction of various types of gene proved to enhance certain characteristics in fish, such as the $\mathrm{GH}$ gene transfer can increase fish growth Mud Loach (Nam et al., 2001), cecropin gene transfer can increase endurance medaka against Pseudomonas fluorescents and Vibrio anguillarum (Sarmasik et al., 2000), and the AFP gene transfer can increase the tolerance of Atlantic salmon on cold temperatures (Hew et al., 1992). 


\section{CONCLUSION}

Sperm was electroporated at $50 \mathrm{~V}$ showed best motility (40\%-55\%) and hatching rate (92.5\%$100 \%$ ). The presence of GFP gene can be detected in all electroporated sperm and in the sperm that was only incubated in the medium containing the GFP gene. As for the larvae, GFP gene was found only in larvae developed from eggs fertilized by electroporated sperm. Thus, electroporated sperm can be a carrier for introducing exogenous gene for producing transgenic stripped catfish.

\section{REFERENCES}

Anzar, M. \& Buhr, M.M. 2006. Spontaneous uptake of exogenous DNA by bull spermatozoa. Theriogenology, 65: 683-690.

Arezzo, F. 1989. Sea urchin sperm as vector for foreign genetic information. Cell Biol. Int. Rep., 13: 391-404.

Brackett, B.G., Baranaska, W., Sawiicki, W., \& Koprosky. 1971. Uptake of heterologous genome by mammalian spermatozoa and its transfer to ova through fertilization. Proc. Natl. Acad. Sci. USA, 68: 353-357.

Cheng, C.A., Lu, K.L., Lau, E.L., Yang, T.Y., Lee, C.Y., Wu, J.L., \& Chang C.Y. 2002. Growth promotion in ayu (Plecoglossus altivelis) by gene transfer of the rainbow trout growth hormone gene. Zoological Studies, 41 (3): 303-310.

Hafez, E.S.E. 1987. Reproduction in farm ani$\mathrm{mals}$, 5 th ed. Lea and Febiger. Philadelphia, $382 \mathrm{pp}$.

Hew, C.L., Davies, O.L., \& Fletcher, G.L. 1992. Antifreeze protein gene transfer in Atlantic salmon. Mol. Mar. Biol. Biotech., 1: 309317.

Hidayani, A. 2009. Isolasi dan efektivitas promoter beta actin dalam mengarahkan ekspresi gen target pada transgenesis ikan mas [tesis]. Bogor: Program Pascasarjana, Institut Pertanian Bogor, $92 \mathrm{hlm}$.

Inoue, K., Yamashita, S., Hata, J., Kabeno, S., Asada, S., Nagahisa, E., \& Fujita, T. 1990. Electroporation as a new technique for producing transgenic fish. Cell Differ. Dev., 29: 123-128.

Knight, D.E. 1981. Rending cells permeable to exposure to electric fields. Tech. Cell Physiol., 113: 1-10.

Knight, D.E., \& Scrutton, M.C. 1986. Gaining access to the cytosol: the technique and some application of electropermeabilization. Biochem. J., 234: 497-506.

Lanes, C.F.C., Sampaio, L.A., \& Marins, L.F. 2009. Evaluation of DNase activity in seminal plasma and uptake of exogenous DNA by spermatozoa of the Brazilian flounder Paralichthys orbignyanus. Theriogenology, 71: 525-533.

Lavitrano, M., Camaioni, A., Faizo, V., Dolci, S., Farace, M.G., \& Spadafora, C. 1989. Sperm cells as vectors of foreign DNA: genetic transformation of mice. Cell, 57: 71 7-723.

Lin, S., Gaiano, N., Culp, P., Burns, J.C., Friedmann, T., \& Yee, J.K. 1994. Integration and germ-line transmission of a pseudo typed retroviral vector in zebrafish. Science, 265: 666-669.

Lu, J.K., Fu, B.H., Wu, J.L., \& Chen, T.T. 2002. Production of transgenic silver sea bream (Sparus sarba) by different gene transfer methods. Mar. Biotechnol., 4: 328-337.

Nam, Y.K., Noh, J.K., Cho, Y.S., Cho, H.J., Cho, K.N., Kim, G., \& Kim, D.S. 2001. Dramatically accelerated growth and extraordinary gigantism of transgenic mud loach Misgurnus mizolepis. Transgenic Research, 10: 353362.

Ozato, K., Kondoh, H., Inohara, H., Iwamatsu, T., Wakamatsu, Y., \& Okada, T.S. 1986. Production of transgenic fish: introduction and expression of chicken $\delta$-crystallin gene in medaka embryos. Cell Differ., 19: 237-244.

Patil, J.G. \& Khoo, H.W. 1996. Nuclear internalization of foreign DNA by zebrafish spermatozoa and its enhancement by electroporation. The J. of Experimental Zoology, 274: 121-129.

Powers, D.A., Hereford, L., Cole, T., Chen, T.T., Lin, C.M., Kight, K., Creech, K., \& Dunhan, R. 1992. Electroporation: a method for transferring genes into the gametes of zebrafish (Brachydanio rerio), channel catfish (Ictalurus punctatus) and common carp (Cyprinus carpio). Mol. Mar. Biol. Biotech., 1: 301-308.

Sarmasik, A., Warr, G., \& Chen, T.T. 2002. Production of transgenic medaka with increased resistance to bacterial pathogen. Mar. Biotechnol., 4: 310-322.

Serpeusu, E.H., Kinosita, K., \& Tsong, T.Y. 1985. Reversible and irreversible modification of erythrocytes by electrical breakdown. Biochim Biophys Acta, 816: 332. 
Sin, F.Y.T., Walker, S.P., Symonds, J.E., Mukherjee, U.K., Khoo, J.G.I., \& Sin, I.L. 2000. Electroporation of salmon sperm for gene transfer: efficiency, reliability, and fate of transgene. Molecular Reproduction and Development, 56: 285-288.

Symonds, J.E., Walker, S.P., Sin, F.Y.T., \& Sin, I.L. 1994. Development of a mass gene transfer method in chinook salmon: optimization of gene transfer by electroporated sperm. Mol. Mar. Biol. Biotech., 3: 104-111.

Tsai, H.J., Tseng, F.S., \& Liao, I.C. 1995. Electroporation of sperm to introduce foreign DNA into the genome of loach (Misgurnus anguilicaudatus). Can. J. Fish. Aquat. Sci., 52: 776-787.
Tsai, H.J. 2000. Electroporated sperm mediation of a gene transfer system for finfish and shellfish. Molecular Reproduction and Development, 56: 281-284.

Tsong, T.Y. 1983. Voltage modulation of membrane permeability and energy utilization in cells. Biosci. Rep., 3: 487-505.

Yazawa, R., Hirono, I., Yamamoto, E., \& Aoki, T. 2005. Gene transfer for Japanese flounder fertilized eggs by particle gun bombardment. Fisheries Sci., 71: 869-874.

Zhong, J., Wang, Y., \& Zhu, Z. 2002. Introduction of the human lactoferin gene into grass carp (Ctenopharyngodon idellus) to increase resistance against GCH virus. Aquaculture, 214: 93-101. 